\title{
Mismatch effect on fatigue crack propagation limit curves of S690QL, S960QL and S960TM type base materials and their gas metal arc welded joints \\ Uticaj neusklađenosti na granične krive širenja zamornih prslina osnovnih materijala tipa S690KL, S960KL i S960TM i njihovih, elektrolučno u zaštiti gasa, zavarenih spojeva
}

Originalni naučni rad / Original scientific paper

Rad je u izvornom obliku objavljen u okviru 72. IIW godišnje

Skupštine $i$ međunarodne konferencije održane u BratislaviSlovačka 07-12. Jula 2019

Rad primljen / Paper received:

Maj 2020.

Ključne reči: Čelici povišene čvrstoće, elektrolučno zavarivanje u zaštiti gasa, efekat neusklađenosti, rast zamornih prslina, dizajna ili granične krive

\section{Abstract}

Nowadays, one of the basic trends in the industry is the environmental impact reduction, in other words the weight decreasing of structural elements and structures, which can be approached by applying different high strength steels. In case of different steel structures, the main manufacturing and joining technology is the welding, the conventional and advanced methods of fusion and pressure welding processes. Beside the weight decreasing, the reliability and safety requirements according to steel structures have significant grown. During the welding process, the welded parts are affected with heat-effect and mechanical loads, which result in inhomogeneous welded joint. The inhomogeneity of the welded joints appears both in microstructural (local) and in geometrical (both local and global) aspects. The changes in microstructure and geometry appear in deflections (basically acceptable), or rather in failures (basically unacceptable); and these influence both the behaviour and the loadability of welded joints. Discontinuities in base materials and their welded joints have especially high danger in case of cyclic loading conditions, which are typical for different structures and structural elements (e.g. bridges, vehicles).

There are different standards and prescriptions containing fatigue crack propagation limit curves and rules for the prediction of the crack growth; simple and two-stage crack growth relationships can be found in the literature, most frequently based on the Paris-Erdogan law. The paper summarizes and presents the results according to our fatigue crack growth investigations on Weldox 700E and Weldox 960E quenched and tempered
Adresa autora / Author's address:

Institute of Materials Science and Technology, Faculty of Mechanical Engineering and Informatics, University of Miskolc, Miskolc-

Egyetemvaros, Hungary

ajanos.lukacs@uni-miskolc.hu, bmobark.mechanical@gmail.com

Keywords: high strength steel, gas metal arc welding, mismatch effect, fatigue crack growth, design or limit curve

\section{Rezime}

Danas je jedan od osnovnih trendova u industriji, smanjenje uticaja na životnu sredinu, drugim rečima smanjenje težine konstrukcijskih elemenata i konstrukcija kojima se može pristupiti primenom različitih čelika velike čvrstoće. U slučaju različitih čeličnih konstrukcija, glavna tehnologija proizvodnje i spajanja je zavarivanje, konvencionalnim i naprednim postupcima zavarivanja topljenjem i pritiskom. Pored smanjenja težine, zahtevi za pouzdanost i sigurnost čeličnih konstrukcija su značajno porasli. Tokom procesa zavarivanja, na zavarene delove utiču toplotna i mehanička opterećenja, što rezultira nehomogenim zavarenim spojem. Nehomogenost zavarenih spojeva pojavljuje se i u mikr strukturi (lokalni) i u geometrijskim (i lokalnim i globalnim) aspektima. Promene mikrostrukture i geometrije pojavljuju se u odstupanjima (u osnovi prihvatljivo), ili bolje rečeno u lomovima (u osnovi neprihvatljivo); a oni utiču i na ponašanje i na nosivost zavarenih spojeva. Prekidi u osnovnim materijalima i njihovim zavarenim spojevima imaju posebno veliku opasnost u slučaju cikličnih opterećenja, koji su tipični za različite konstrukcije i konstrukcijske elemente (npr. mostovi, vozila).

Postoje različiti standardi i preporuke koji sadrže granične krive širenja zamorne prsline i pravila za predviđanje rasta prslina; u literaturi se mogu naći jednostavni i dvostepeni odnosi rasta prslina, koji se najčešće zasnivaju na Paris-Erdogan-ovom zakonu. Rad rezimira i prikazuje rezultate prema našim istraživanjima rasta prslina na Weldox 700E i Weldox 960E kaljeni i otpušteni $(Q+T)$ i na Alform 960M termomehanički obrađenom (TM) čeliku 
$(\mathrm{Q}+\mathrm{T})$ and on Alform 960M thermomechanically treated (TM) high strength steel base materials and their gas metal arc welded joints. The mismatch effect has also been studied; matched, overmatched, undermatched and matched/overmatched (mixed-matched) welded joints were investigated. $15 \mathrm{~mm}$ thick plates were used for the investigations, statistical aspects were applied both for presenting the possible crack locations in the real plates, as well as for processing the measured data. Furthermore, the results will be compared with each other, and fatigue crack propagation limit curves will be derived using simple crack growth relationship.

\section{Introduction}

Reliability of a structural element having crack or cracklike defect under cyclic loading conditions is determined by the geometrical features of the structural element and the flaws, the loading conditions, as well as the material resistance to fatigue crack propagation. There are different documents [1-3], standards and recommendations [4-6] containing fatigue crack propagation limit or design curves and rules for the prediction of the crack growth $[6,7]$. The background of the fatigue crack propagation limit curves and the calculations consist of two basic parts: statistical analysis of numerous investigations (fatigue crack propagation tests) and fatigue crack propagation law, frequently the Paris- Erdogan law [8],

$$
\frac{d a}{d N}-C \Delta K^{n},
$$

where da/dN is the fatigue crack growth rate, $\Delta \mathrm{K}$ is the stress intensity factor range, furthermore $\mathrm{C}$ and $\mathrm{n}$ are material constants.

The research work and this paper aimed

to characterise the fatigue crack propagation resistance of different high strength structural steels and their welded joints using limit curves [9, 10], based on statistical analysis of test results and the Paris-Erdogan law;

determination of limit curves for different high strength structural steels and their gas metal arc welded joints, under mode I (tension) loading condition.

\section{Testing circumstances}

\subsection{Materials}

$15 \mathrm{~mm}$ thick plates were used for the welding and the base materials and welded joints investigations of SSAB Weldox 700E (abbreviated: W700E) and VOESTALPINE Alform 960M (abbreviated: A960M) material grades. $15 \mathrm{~mm}$ thick SSAB Weldox $960 \mathrm{E}$ (abbreviated W960E) plate was tested during the visoke čvrstoće osnovni materijali i njihovi spojevi zavareni elektrolučno u zaštiti gasa. Efekat neusklađenosti je takođe proučen; ispitivani su podudarni, jači (overmatched ), slabiji (undermatched), podudarni i podudarni / jači (mešani) zavareni spojevi. Korišćene su ploče debljine $15 \mathrm{~mm}$ za istraživanja, primenjeni su statistički aspekti i za predstavljanje mogućih lokacija prslina u stvarnim pločama, kao i za obradu izmerenih podataka. Pored toga, rezultati će se upoređivati jedan sa drugim i sa graničnom krivom širenja zamorne prsline će se izvesti pomoću jednostavnog odnosa rasta prslina.

\section{Uvod}

Pouzdanost konstrukcijskog elementa koji ima prslinu ili defekt koji liči na prslinu u uslovima cikličnog opterećenja, određuje se pomoću geometrijskih karakteristika konstrukcijskog elementa i nedostaci, uslovi opterećenja, kao i otpornost materijala na širenje prslina. Postoje različiti dokumenti [1-3], standardi i preporuke [4-6] koji sadrže granicu širenja zamorne prsline ili konstrukcijske krive i pravila za predviđanje rasta prsline $[6,7]$. Pozadina granične krive širenja zamorne prsline i proračuni se sastoje od dva osnovna dela: statistička analiza brojnih istraživanja (testovi širenja zamorne prsline) i zakon o širenju zamorne prsline, poznat kao Paris- Erdogan-ov zakon [8],

$$
\frac{d a}{d N}-C \Delta K^{n},
$$

gde je da / dN stopa rasta zamorne prsline, $\Delta \mathrm{K}$ je raspon faktora intenziteta napona, dalje su $\mathrm{C}$ i $\mathrm{n}$ materijalne konstante materijala .

Istraživački rad i ovaj rad imaju za cilj

- okarakterisati otpornost na širenje prslina kod različitih konstrukcionih čelika visoke čvrstoće i njihovih zavarenih spojeva koristeći granične krive $[9,10]$, zasnovane na statističkoj analizi rezultata ispitivanja i Paris-Erdogan-ovom zakonu;

- određivanje graničnih krivih za različite konstrukcione čelike visoke čvrstoće i njihove spojeve elektrolučno zavarene u zaštiti gasa, pod režimom opterećenja I (zatezanje)

\section{Podaci o ispitivanju}

\subsection{Materijali}

Ploče debljine $15 \mathrm{~mm}$ korišćene su za ispitivanje zavarivanja, osnovnih materijala i zavarenih spojeva SSAB Weldox 700E (skraćeno: W700E) i VOESTALPINE Alform 960M (skraćeno: A960M). $15 \mathrm{~mm}$ debljina SSAB Weldox 960E (skraćeno 
base material examinations, too (designated Weldox 960E-BM and abbreviated W960E); furthermore, $20 \mathrm{~mm}$ thick plates were welded and investigated (designated Weldox 960E-WJ and abbreviated W960E). Böhler UNION X85, UNION X90 and UNION X96 (abbreviated X85, X90 and $X 96$, respectively) filler metal were used for the production of welded joits. The chemical composition of the base materials and the filler metals, and the mechanical properties can be seen based on quality certificates in Tab. 1 and Tab. 2, respectively. Based on the data given in Tab. 1 and Tab. 2, it can be found that the two Weldox 960E base materials are the same.
W960E) ploča testirana je i tokom ispitivanja osnovnog materijala (označena Weldox 960E-BM i skraćeno W960E); dalje su zavarene i istražene ploče debljine $20 \mathrm{~mm}$ (označene sa Weldox 960EVJ i skraćeno W960E). Za izradu zavarenih spojeva korišćeni su Bohler UNION X85, UNION X90 i UNION X96 (skraćeno X85, X90 i X96) dodatni materijali. Hemijski sastav osnovnih i dodatnih materijala i mehanička svojstva mogu se videti na osnovu potvrda kvaliteta u Tab. $1 \mathrm{i}$ Tab. 2, respektivno. Na osnovu podataka datih u Tab. 1 i Tab. 2, može se utvrditi da su dva osnovna materijala Weldox 960E ista.

\begin{tabular}{|c|c|c|c|c|c|}
\hline Material Designation & $\bar{c}$ & SI & $M=$ & $\bar{P}$ & 5 \\
\hline Weidex root & 0.14 & 0.30 & 1.13 & 0,007 & 0.001 \\
\hline Union X:SS & 0.07 & 0.68 & 1.62 & a.020 & 0.010 \\
\hline Union $X 90$ & 0.10 & 0.8 & 1.8 & $N / A$ & $N / A$ \\
\hline Weidex 960t-BM & 0.16 & 0.22 & 1.24 & 0.009 & 0.001 \\
\hline Weidus 9606-WI & 0.16 & 0.23 & 1.25 & 0.008 & 0.001 \\
\hline Alform 960M & 0.004 & a.329 & 1.65 & a.011 & 0.0006 \\
\hline Unibn X96 & 0.1 & 0.81 & 194 & 0.015 & 0.011 \\
\hline Material Designation & $\alpha$ & $\mathrm{Ni}$ & Mo & $\mathrm{v}$ & $\pi$ \\
\hline Weidex 700E & 0.30 & 0.04 & 0.167 & a.011 & 0.009 \\
\hline Unibn X:S & 0.29 & 1.73 & 0.61 & 0.01 & 0.08 \\
\hline Union $\times 90$ & 0.35 & 2.3 & 0.6 & $N / A$ & $N / A$ \\
\hline Weidox 9605-BM & 0.19 & 0.05 & 0.581 & 0.041 & 0.004 \\
\hline Weblex 9606-Wh & 0.20 & 0.04 & 0.605 & 0.04 & 0.004 \\
\hline Aflom $960 \mathrm{M}$ & 0.61 & 0.026 & 0.29 & 0.078 & 0.014 \\
\hline Union X56 & 0.52 & 2.28 & 0.53 & 0.01 & 0.06 \\
\hline Material Designation & 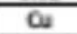 & AI & $\mathrm{NB}$ & $B$ & $N$ \\
\hline Weidex root & 0.01 & 0.34 & 0.001 & $a, 0,2$ & 0.003 \\
\hline Unien XES & 0.06 & 0.01 & $N / A$ & N/A & $N / A$ \\
\hline Union $X 90$ & $\mathrm{~N} / \mathrm{A}$ & $N / A$ & $N / A$ & $N / A$ & N/A \\
\hline Weldex 960t-BM & 0.01 & 0.056 & 0.016 & $a, \infty 1$ & 0.003 \\
\hline Wekfon 9606-WI & 0.01 & 0.06 & 0.016 & 0.001 & 0.003 \\
\hline Alorm 960M & 0.016 & a.038 & 0.035 & 0.0015 & 0.006 \\
\hline Union X56 & 0.06 & $<0.01$ & $\mathrm{~N} / \mathrm{A}$ & $N / 2$ & N/A \\
\hline
\end{tabular}

Tab. 1 The chemical composition of the examined base materials and filler metals [weight \%]

Tab. 1 Hemijski sastav ispitivanih osnovnih i dodatnih materijala [težinski \%]

\begin{tabular}{|c|c|c|c|c|}
\hline $\begin{array}{c}\text { Material } \\
\text { Desixtation }\end{array}$ & $\begin{array}{c}\text { Ras } \\
\text { [MPa) }\end{array}$ & $\begin{array}{c}\mathrm{R} \\
\text { [MPel }\end{array}$ & $\stackrel{A}{[\times]}$ & $\begin{array}{c}\text { CVN impact enersy } \\
\text { Ø }\end{array}$ \\
\hline Weldar 7006 & 791 & 836 & 17.0 & $-40^{\circ} \mathrm{C}: 165$ \\
\hline UNION $\times 95$ & 2790 & 2880 & $\geq 16.0$ & $50^{\circ} \mathrm{C} \geq 47 ; 20^{\circ} \mathrm{C} \geq 90$ \\
\hline UNION Xoo & 2890 & 2950 & $\geq 15.0$ & $50^{\circ} \mathrm{C} \geq 47,20^{\circ} \mathrm{C} \geq 90$ \\
\hline Weidex 960E-BM & 1000 & 2045 & 16.0 & $-40^{\circ} \mathrm{C}: 241$ \\
\hline Weldar 9606-WI & 1000 & 2063 & 16.0 & $-40^{\circ} \mathrm{C}: 205$ \\
\hline Aform 960M & 1051 & 2058 & 169 & $-40^{2} \mathrm{C}: 20$ \\
\hline UNion $\times 96$ & 2930 & 2980 & 214.0 & $50^{\circ} \mathrm{C} \geq 47 ; 200<280$ \\
\hline
\end{tabular}

Tab. 2 The mechanical properties of the examined base materials and filler metals Tab. 2 Mehanička svojstva ispitivanih osnovnih i dodatnih materijala

\subsection{Welding circumstances}

The dimensions of the welded workpieces were $300 \mathrm{~mm} \times 125 \mathrm{~mm}$. For the equal stress distribution X-grooved (double V-grooved) welding joints were used, with $80^{\circ}$ opening angle and with $2 \mathrm{~mm}$ gap between the two plates. The welding equipment was a Daihen Varstroj Welbee Inverter P500L (WBP500L) MIG/MAG power source; $1.2 \mathrm{~mm}$ diameter solid wires and $18 \% \mathrm{CO} 2+82 \%$ Ar gas mixture (M21) were applied. The root layers (2 layers) were made by a qualified welder, while the filler layers ( 6

\subsection{Podaci o zavarivanju}

Dimenzije zavarenih komada su bile 300 mm k 125 $\mathrm{mm}$. Za jednaku raspodelu naprezanja korišćeni su $X$ žljebovi (dvostruki $V$ žljebovi), sa uglom otvora 80 - i zazorom od $2 \mathrm{~mm}$ između dve ploče. Oprema za zavarivanje je bio Daihen Varstroj Velbee Inverter P500L (VB-P500L) MIG / MAG izvor napajanja; Primenjene su pune žice prečnika $1,2 \mathrm{~mm}$ i gasna smeša $18 \% \mathrm{CO}_{2}+82 \% \operatorname{Ar}(\mathrm{M} 21)$. Korenske slojeve (2 sloja) napravio je kvalifikovani zavarivač, dok su slojevi ispune (6 slojeva za ploče debljine $15 \mathrm{~mm}$ ili 
layers for $15 \mathrm{~mm}$ thick plates or 10 layers for 20 $\mathrm{mm}$ thick plates) by an automated welding car, in all cases. During the welding process, the workpieces were rotated systematically, after each layer. The applied mismatch characteristics (base materials and filler metals pairing) can be found in Tab. 3.
10 slojeva za ploče debljine $20 \mathrm{~mm}$ ) izvedeni automatskim zavarivačkim vozilom. Tokom procesa zavarivanja, radni komadi se sistematski rotiraju, nakon svakog sloja. Primenjene karakteristike neusklađenosti (uparivanje osnovnih materijala i dodatnih materijala) mogu se naći u Tab. 3 .

\begin{tabular}{|c|c|c|}
\hline Base material & Mismatch type & Filler metal \\
\hline Weldox 700E & menthing $(\mathrm{M})$ & UNON $\times 85$ \\
\hline Weldox 700E & overmendhinx (OM) & UNONX90 \\
\hline Weldox 700E & $\begin{array}{l}\text { root levers: matching / filer layers: } \\
\text { evermatching (M/OM) }\end{array}$ & UNION $\times A 5 / \times 90$ \\
\hline Weldox $960 \mathrm{E}$ & matdhifx (M) & UNoN 096 \\
\hline Allorm $960 \mathrm{M}$ & undermanchins (UM) & UNONX90 \\
\hline Alsorm $960 \mathrm{M}$ & mandhifx (M) & UNONX96 \\
\hline
\end{tabular}

Tab. 3 Mismatch characteristics: the applied base materials and filler metals pairing Tab. 3 Karakteristike neusklađenosti: uparivanje osnovnih i dodatnih materijala

The welding parameters were selected based on both theoretical considerations [11-15] and real industrial applications. A welding monitoring system (WeldQAS, developed and delivered by HKSProzesstechnik GmbH [16]) was used for the registration of the welding parameters. Based on the registered data, the applied welding parameters (average or range values) were summarized in Tab. 4. The table shows the welding current (I), the voltage $(U)$ and the welding speed $(\mathrm{vw})$ values, also the preheating (Tpre) and the interpass (Tip) temperatures, with the linear energy (Ev) and the calculated critical cooling time (t8.5/5) values. The parameters of the root and the filler layers were summarized separately
Parametri zavarivanja su odabrani na osnovu teorijskih razmatranja [11-15] i stvarnih industrijskih primena. Za registraciju parametara zavarivanja korišćen je sistem za nadgledanje zavarivanja (WeldQAS, koji je razvio i isporučio HKSProzesstechnik $\mathrm{GmbH}$ [16]). $\mathrm{Na}$ osnovu registrovanih podataka, primenjeni parametri zavarivanja (prosečne ili raspon vrednosti) sumirani su u Tab. 4. U tabeli su prikazane vrednosti struje zavarivanja (I), napona (U) i brzine zavarivanja (vw), takođe temperature predgrevanja (Tpre) i međuslojne temperature (Tip), sa linearnom energijom (Ev) i izračunatom vrednosti kritičnog vremena hlađenja (t8.5 / 5). Parametri za sloja korena i slojeve ispune su sažeti odvojeno.

\begin{tabular}{|c|c|c|c|c|}
\hline $\begin{array}{c}\text { Base material// } \\
\text { filer metal }\end{array}$ & Layer & $\begin{array}{c}\mathrm{T}_{\mathrm{ma}} \mathrm{T}_{4} \\
\mathrm{FC}\end{array}$ & $\begin{array}{c}1 \\
{[A]}\end{array}$ & $\begin{array}{c}U \\
\mathrm{~N}\end{array}$ \\
\hline \multirow{2}{*}{$\begin{array}{c}\text { Wroce / } \times 8.5 \\
\text { Wroot / X90 } \\
\text { wroot / Xas } \times 90\end{array}$} & $1-2$ root & 150 & $130-140$ & 19.0 .205 \\
\hline & 3-8 filer & 180 & $280-300$ & 28.5 .29 .5 \\
\hline \multirow[t]{3}{*}{ W960e / $\times 96$} & 1 root & 200 & 96 & 17.3 \\
\hline & 2 root & 180 & 194 & 22.0 \\
\hline & 3-12 filer & 150 & $298-308$ & 29.0 .31 .0 \\
\hline \multirow{2}{*}{$\begin{array}{l}\text { W960M / } \times 00 \\
\text { W960M / X96 }\end{array}$} & $1-2$ foot & 60 & $130-140$ & 19.0 .20 .5 \\
\hline & 3-8 flez & 150 & $270-300$ & 27.28 .0 \\
\hline $\begin{array}{c}\text { Base material/ } \\
\text { filer metal }\end{array}$ & Layer & $\begin{array}{c}\mathrm{v}_{\mathbf{z}} \\
{[\mathrm{cm} / \mathrm{min}]}\end{array}$ & $\frac{E}{\mathrm{E} / \mathrm{m}=1}$ & $\begin{array}{l}\operatorname{lan} n \\
{[\mathrm{~b}]}\end{array}$ \\
\hline \multirow{2}{*}{$\begin{array}{c}\text { wroce } / \times 85 \\
\text { wroot } / \times 90 \\
\text { wroot } / \times a 5 / \times 90\end{array}$} & $1-2$ rool & 20 & $700-750$ & $7-8$ \\
\hline & 3-8 file: & 40 & $1000-1200$ & $9-11$ \\
\hline \multirow[t]{3}{*}{ W960E / X96 } & 1 foot & 11 & $m 7$ & 6.7 \\
\hline & $2 \mathrm{root}$ & 27 & 764 & 6.5 \\
\hline & 3-12 filet & 45 & $940-1000$ & 7.8 \\
\hline \multirow{2}{*}{$\begin{array}{l}\text { W960M / } \times 90 \\
\text { W960M / X96 }\end{array}$} & $1-2$ root & 20 & $700-750$ & $7-8$ \\
\hline & 3-8 nilez & $30-45$ & $900-1400$ & $7-15$ \\
\hline
\end{tabular}

Tab. 4 Applied welding parameters

Tab.4 Primenjeni parametri zavarivanja 


\subsection{Fatigue crack growth tests}

The FCG tests were executed on three-point bending (TPB) specimens, nominal $W$ values were $26 \mathrm{~mm}(\mathrm{t}=15 \mathrm{~mm})$ and $28 \mathrm{~mm}(\mathrm{t}=20 \mathrm{~mm})$, and 13 $\mathrm{mm}(\mathrm{t}=15 \mathrm{~mm})$ and $18 \mathrm{~mm}(\mathrm{t}=20 \mathrm{~mm})$ for the base materials and the welded joints, in the 21 and 23 directions, respectively. The position of the notches correlated with the rolling direction (T-L, L$\mathrm{T}, \mathrm{T}-\mathrm{S}$ and L-S). The positions of the cut specimens from the and 23W) were used (Fig. 2). Fig. 3 shows one possible location of the noth in the thickness direction (23W). welded joints is shown in Fig. 1, 21 and 23 directions (21W).

\subsection{Testovi rasta zamorne prsline}

Testovi rasta zamorne prsline (FCG)su izvedeni na uzorcima savijanjem $u$ tri tačke (TPB), nominalne vrednosti $W$ su bile $26 \mathrm{~mm}(\mathrm{t}=15 \mathrm{~mm})$ i $28 \mathrm{~mm}(\mathrm{t}=$ $20 \mathrm{~mm})$, a $13 \mathrm{~mm}(\mathrm{t}=15 \mathrm{~mm})$ i $18 \mathrm{~mm}(\mathrm{t}=20 \mathrm{~mm})$ za osnovne materijale i zavarene spojeve, u smeru 21 i 23, respektivno. Položaj zareza je u korelaciji sa pravcem valjanja (T-L, L-T, T-S i L-S). Korišćeni su položaji isečenih uzoraka od i 23W) (SI. 2). SI. 3 prikazuje jednu moguću lokaciju zareza u pravcu debljine (23W). zavareni spojevi prikazani su na slikama 1, 21 i 23 smera (21W).

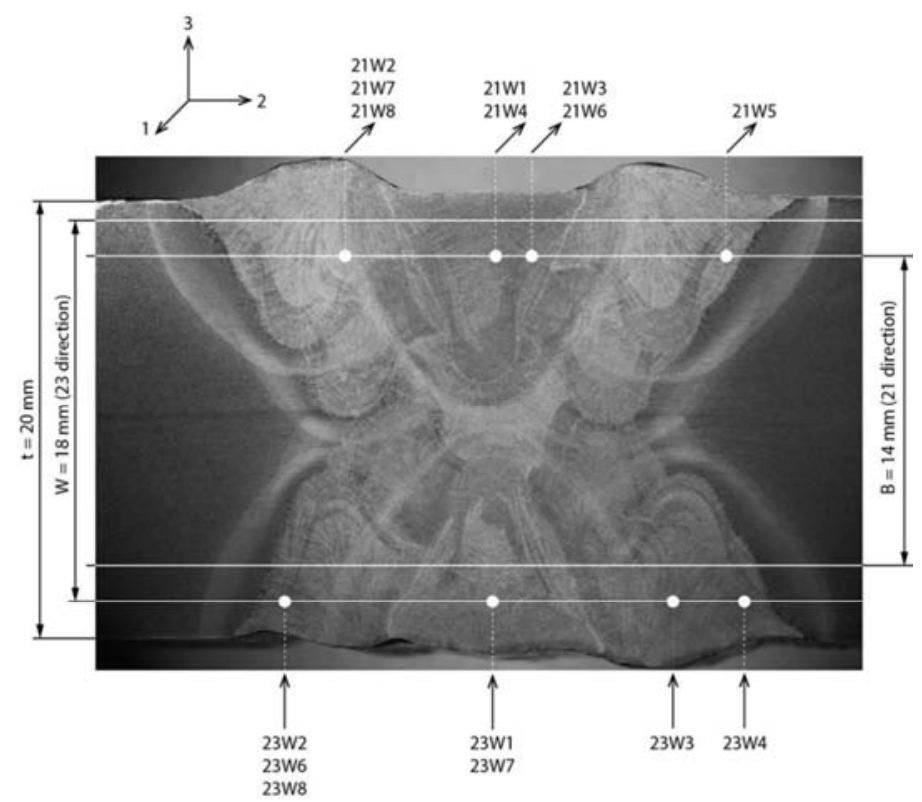

Fig. 1 TPB specimen locations in the Weldox 960E / UNION X96 welded joints with the crack paths (21W and 23W) SI. 1 Lokacije uzoraka za savijanje u tri tačke (TPB) Weldox 960E / UNION X96 zavarenim spojevima sa prslinama $(21 W$ i $23 W)$

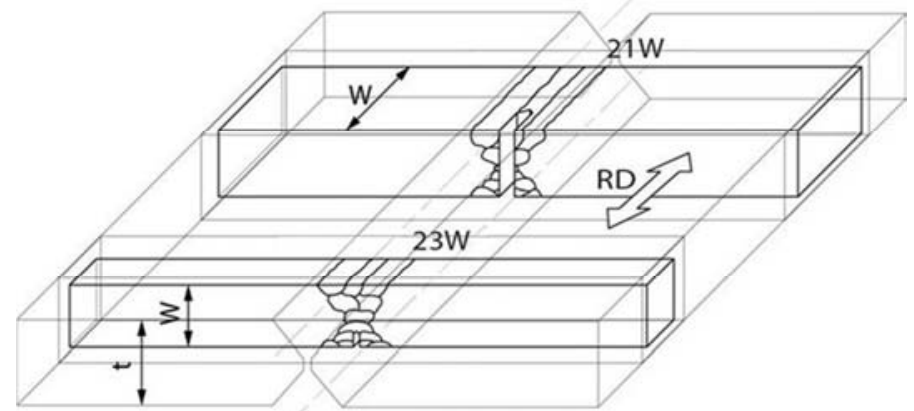

Fig. 2 TPB specimen locations in the welded joint with the notch directions (RD = rolling directions)

SI. 2 Položaji uzoraka TPB u zavarenom spoju sa smerovima zareza ( $R D=$ pravci valjanja)

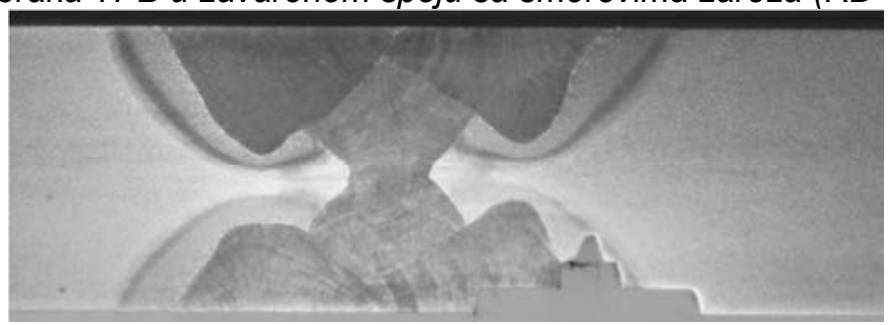

Fig. 3 One possible location of the notch in the thickness direction

SI. 3 Jedno moguće mesto zareza u smeru debljine 
The notch locations, the notch distances from the centreline of the welded joints, were different, therefore the positions of the notches and the crack paths represent the most important and the most typical crack directions in a real welded joins. Postweld heat treating was not applied after welding on GMAW joints (investigations in as-welded condition).

The FCG examinations were performed with tensile stress, $R=0.1$ stress ratio, sinusoidal loading wave form, at room temperature, and on laboratory air, using MTS type electro-hydraulic testing equipment. The loading frequency was $f=20 \mathrm{~Hz}$ for two-thirds of the growing crack's length, approximately, and it was $\mathrm{f}=5 \mathrm{~Hz}$ for the last third. The propagating crack was registered with optical method, using video camera and hundredfold magnification $(\mathrm{N}=100 \mathrm{x})$.

\section{Results of examinations}

\subsection{Hardness distribution}

HV10 hardness values were measured along two lines, as it can be seen in Fig. 4, furthermore Fig. 5 shows the hardness distributions (Weldox 700E / UNIONX85/UNION X90).
Lokacije zareza, udaljenosti zareza od središnje linije zavarenih spojeva, bili su različiti, pa su položaji zareza i prslina najvažniji i najtipičniji pravci prslina u stvarnim zavarenim spojevima. Termička obrada posle zavarivanja na zavarenim spojevima GMAW-MIG/MAG (ispitivanja u stanju zavarivanja) nije primenjena.

FCG ispitivanja izvedena su sa zateznim naponom, odnosom napona $R=0,1$, sinusoidnim talasnim opterećenjem, na sobnoj temperaturi i na laboratorijskom vazduhu, koristeći elektrohidrauličku opremu za ispitivanje tipa MTS. Frekvencija opterećenja bila je $f=20 \mathrm{~Hz}$ za dve trećine rastuće dužine prsline, otprilike, i bila je $f=5$ $\mathrm{Hz}$ za poslednju trećinu. Propagirajuća prslina registrovana je optičkim metodama, korišćenjem video kamere i uvećanjem od 100 puta $(\mathrm{N}=100 \mathrm{x})$.

\section{Rezultati ispitivanja 3.1 Raspodela tvrdoće}

Vrednosti tvrdoće HV10 merene su duž dve linije, kao što se može videti na slici 4 , a na slici 5 prikazane su distribucije tvrdoće (Weldox 700E / UNIONKS85 / UNION X90).

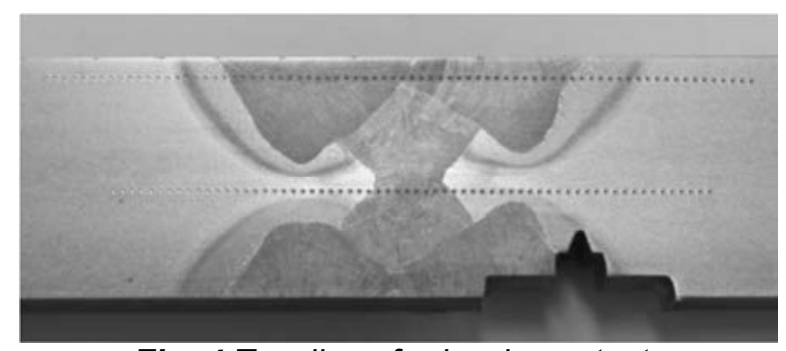

Fig. 4 Two lines for hardness tests

SI. 4 Dve linije za ispitivanja tvrdoće

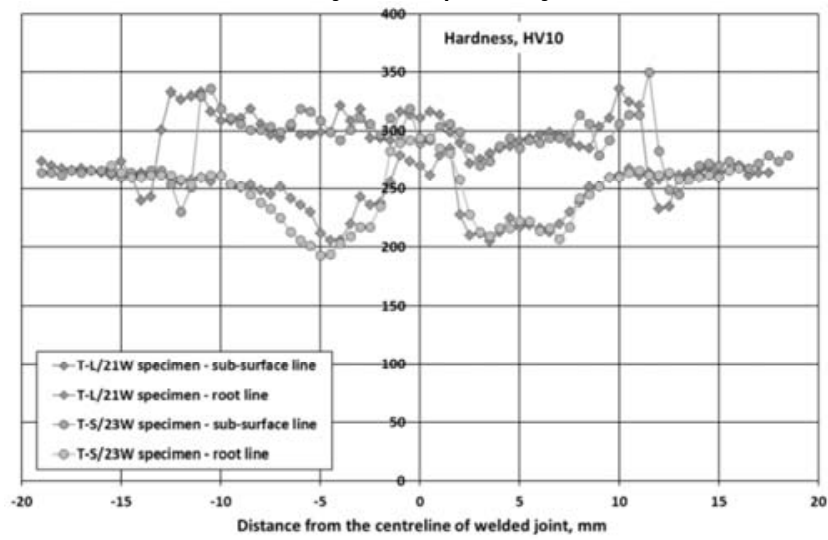

Fig. 5 Hardness distributions measured on Weldox 700E / UNIONX85/UNION X90 specimen

SI. 5 Raspodela tvrdoće merena na uzorku Weldox 700E / UNIONX85/UNION X90

\subsection{Fatigue crack growth tests}

The next figures and Table 5 show selected experimental results on Weldox 700E / UNIONX85/UNION X90 welded joints. The crack length vs. number of cycles curves can be seen in different orientation in Fig. 6 and Fig. 7, and the

\subsection{Testovi rasta zamorne prsline}

Sledeće slike i tabela 5 prikazuju odabrane eksperimentalne rezultate na Weldox 700E / UNIONKS85 / UNION Ks90 zavarenim spojevima. Dužina prsline naspram krivih broja ciklusa može se videti $u$ različitoj orijentaciji na Sl. 6 i Sl. 7, a 
calculated stress intensity factor range vs. fatigue crackgrowth rate values are shown in Fig. 8 (WM = weld metal, $\mathrm{HAZ}=$ heat affected zone, $\mathrm{BM}=$ base material). izračunati raspon faktora intenziteta napona $u$ odnosu na vrednosti brzine rasta zamorne prsline, prikazan je na SI. 8 (WM = metal šava, HAZ = zona pod uticajem toplote, $\mathrm{BM}=$ osnovni materijal).

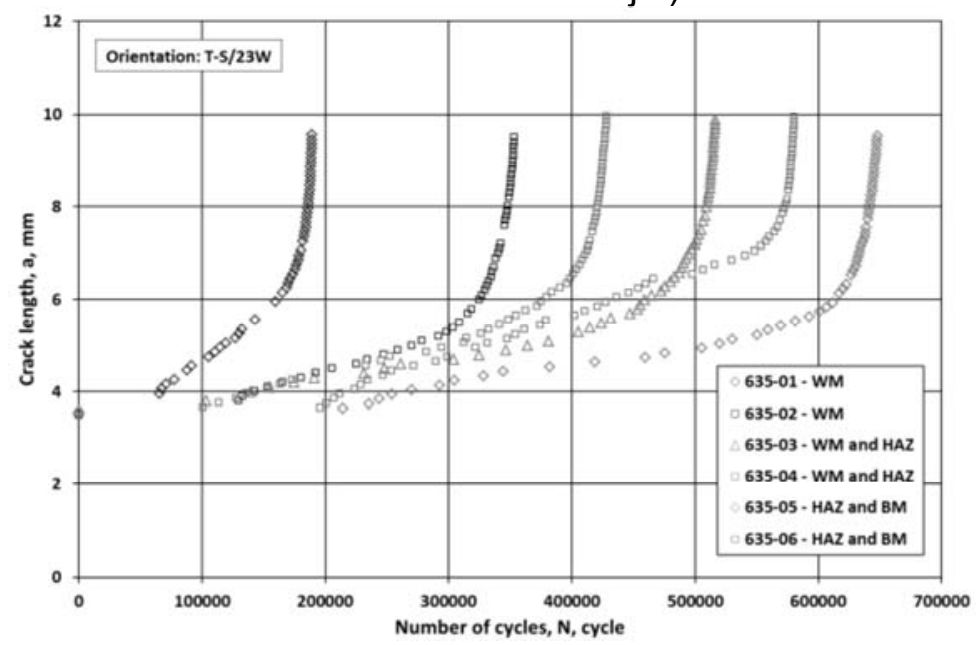

Fig. 6 Crack length vs. number of cycles curves in T-S/23W orientation (Weldox 700E / UNIONX85/UNION X9 SI. 6 Dužina prsline naspram broja ciklusa na pravcu T-S/23W (Weldox 700E / UNIONX85/UNION X90)0)

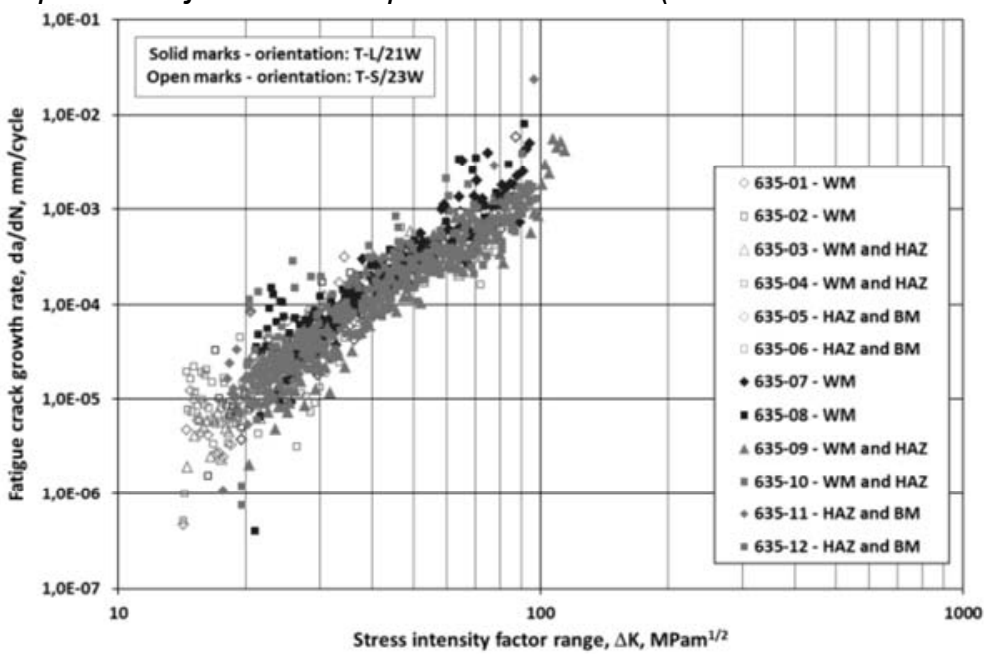

Fig. 8 Results of FCG tests on Weldox 700E / UNIONX85/UNION X90 welded joints (altogether 12 specimens) SI. 8 Rezultati FCG testova na zavarenim spojevima Weldox 700E / UNIONKS85 / UNION X90 (ukupno 12 uzoraka)

Secant method [17] was used to evaluate the fatigue crack growth data. The constants $(C$ and $n)$ of the Paris-Erdogan relationship [8] were calculated using the least squares regression method, and the fatigue fracture toughness $(\Delta \mathrm{Kfc})$ values were determined using the crack length on the crack front measured by stereo microscope. The data belonging to stage II of the kinetic diagram of fatigue crack propagation have been eliminated during the least square regression analysis, for each specimen, systematically.

Tab. 5 summarizes the FCG test results executed on specimens cut from Weldox 700E / UNIONX85/UNION X90 welded joints (Sp ID = specimen ID, Co coe = correlation coefficient).
Za procenu podataka rasta prslina usled zamora korišćena je metoda sekante [17]. Konstante (C i n) Paris-Erdogan-ovog odnosa [8] izračunate su korišćenjem metode najmanje kvadratne regresije, a vrednosti žilavosti preloma usled zamora $(\Delta \mathrm{KfC})$ određene su korišćenjem dužine prsltine na prednjoj strani merene stereo mikroskopom. Podaci koji pripadaju II stadijumu kinetičkog dijagrama širenja prslina usled zamora eliminisani su tokom analize najmanje kvadratne regresije, za svaki uzorak, sistematski.

Tabela. 5 rezimira rezultate FCG ispitivanja izvršenih na uzorcima iz Weldox 700E / UNIONKS85 / UNION X90 zavarenih spojeva (Sp ID = ID uzorak, Co koeficijent korelacije). 


\begin{tabular}{|c|c|c|c|c|c|}
\hline \multirow{2}{*}{ SQ ID } & \multirow{2}{*}{ Crack path } & c & $=$ & \multirow{2}{*}{$\begin{array}{c}C 0000 \\
{[-1}\end{array}$} & \multirow{2}{*}{ 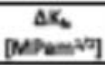 } \\
\hline & & \multicolumn{2}{|c|}{ 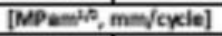 } & & \\
\hline $635-01$ & WM & $5.236-10$ & 330 & 0.9589 & 91.3 \\
\hline $635-02$ & WM & $8.036-10$ & 3.21 & 0.9496 & 76.2 \\
\hline $6.35-03$ & WM/HAZ & $3456-10$ & 343 & 0.5632 & 80.1 \\
\hline $6.35-04$ & WM/HAZ & 4.626 .10 & 3.27 & 0.9205 & 82.1 \\
\hline $6.35-06$ & $\mathrm{Haz} / \mathrm{BM}$ & $2206-10$ & 3.61 & 0.9372 & 68.1 \\
\hline 635.06 & $\mathrm{KA2} / \mathrm{BM}$ & 2136.00 & 24 & 0.9309 & 82.9 \\
\hline 635.07 & WM & 4.426 .10 & 34 & 0.8454 & 95.7 \\
\hline 6.35 .08 & WM & $2725-(0)$ & 297 & 0.9274 & 96.0 \\
\hline $6.35-09$ & WM/ $/ \mathrm{HAZ}$ & $2886-10$ & 336 & 0.9599 & 117.0 \\
\hline $635-10$ & WM/HAZ & 5.006 .09 & 276 & 0.9285 & 98.8 \\
\hline 6.35-11 & $\mathrm{HNZ} / \mathrm{BM}$ & 8.646 .10 & 320 & 0.9613 & 1029 \\
\hline $635-12$ & $\mathrm{KW2} / \mathrm{BM}$ & $2236-09$ & 24 & 0.9354 & 1000 \\
\hline
\end{tabular}

Tab. 5 Fatigue crack propagation test results executed on specimens cut from Weldox 700E / UNIONX85/UNION X90 welded joints

Tab. 5. Rezultati ispitivanja širenja prslina na uzorcima od Weldox 700E / UNION X85 / UNION X90 zavarenih spojeva

\section{Determination of fatigue crack propagation limit curves}

Kinetic diagrams of fatigue crack growth can be simplified and described using both simple and twostage crack growth relationships, as it can be seen in Fig. 9, based on [6]. (In BS $7910 \mathrm{~m}$ is used as Paris-Erdogan exponent, istead of $n$.) According to the main aim of our research work and the paper, the simple crack growth relationship was selected and used.

\section{Određivanje graničnih kriva širenja prslina zamora}

Kinetički dijagrami rasta prslina usled zamora mogu se pojednostaviti i opisati upotrebom jednostavnih i dvostepenih odnosa rasta prslina, kao što se može videti na slici 9, na osnovu [6]. (U BS 7910 m koristi se kao eksponent Paris-Erdogan, umesto n..) Prema glavnom cilju našeg istraživačkog rada $i$ rada odabran je i korišćen jednostavan odnos rasta prslina.

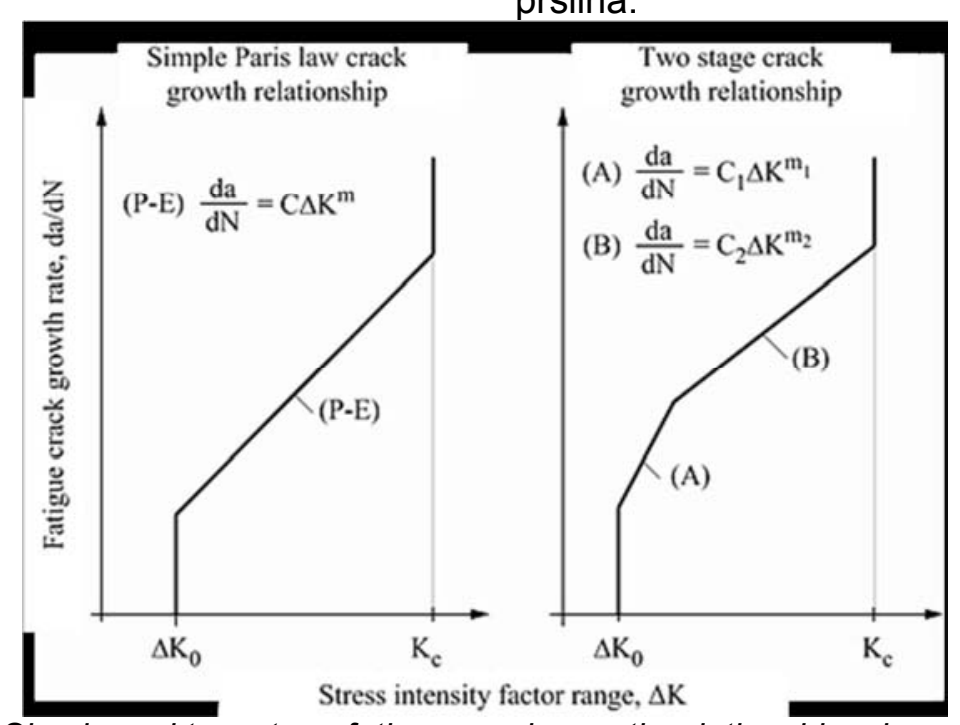

Fig. 9 Simple and two-stage fatigue crack growth relationships, based on [6] SI. 9 Jednostavni i dvostepeni rast zamorne prsline, zasnovan na [6]

Based on the experimental data and results, fatigue crack propagation limit curves can be determined. Generally, the determination of the fatigue design curves consists of six steps, as follows [10]. First step: determination of measuring values, the threshold stress intensity factor range ( $\Delta K$ th), if available, the two parameters of the Paris-Erdogan law (in our case $C$ and $n$ ) and the fatigue fracture toughness $(\Delta \mathrm{Kfc})$. Second step: classification of measured values into statistical samples, on the basis of calculated test results, applying Wilcoxon matched pairs test. Third step: selection of the distribution function type using Shapiro-Wilk, Kolmogorov- Smirnov and chi square
$\mathrm{Na}$ osnovu eksperimentalnih podataka i rezultata mogu se odrediti granične krive širenja prslina usled zamora. Uopšteno, utvrđivanje krivih zamora sastoji se od šest koraka, kako sledi [10]. Prvi korak: određivanje mernih vrednosti, raspon faktora intenziteta praga napona ( $\Delta K$ th), ako su dostupni, dva parametra Paris-Erdoganovog zakona (u našem slučaju $C$ i $n$ ) i žilavost preloma usled zamora $(\Delta \mathrm{Kfc})$. Drugi korak: klasifikacija izmerenih vrednosti u statističke uzorke, na osnovu izračunatih rezultata ispitivanja, primenom testa Wilcokon-ovih podudarnih parova. Treći korak: izbor vrste funkcije distribucije korišćenjem Shapiro-Wilk, Kolmogorov-Smirnov i kvadrata chi 
$\left(\chi^{2}\right)$ goodness of fit tests (testing if sample data fits a distribution from a certain population, i.e. a population with a normal or a Weibull distribution), at a level of significance $\varepsilon=0.05$. After the analysis, it was concluded, that only the three parameter Weibull-distribution function is suitable for describing all the configured samples. Fourth step: calculation of the parameters of the three parameter Weibull-distribution functions. The parameters of the distribution functions were calculated for all the configured samples using the

$$
\mathrm{F}(\mathrm{x})=1-\exp \left[-\left(\frac{\mathrm{x}-\mathrm{N}_{0}}{\beta}\right)^{1 / \alpha}\right]
$$

equation, where N0 is the threshold parameter, $\alpha$ is the shape parameter and $\beta$ is the scale parameter. Fifth step: selection of the characteristic values of the distribution functions. Considering the influencing effects of the material parameters on the life-time estimation, characteristic values of $\Delta \mathrm{Kth}, \mathrm{n}$ and $\Delta \mathrm{Kfc}$ were selected. The threshold stress intensity factor range ( $\Delta K$ th) is that value which belongs to the $95 \%$ probability, the exponent of the Paris-Erdogan law (n) is that value which belongs to the $5 \%$ probability and the fatigue fracture toughness $(\Delta \mathrm{Kfc})$ is that value which belongs to the $5 \%$ probability of the relevant Weibull-distribution function. The Paris-Erdogan constant (C) can be calculated on the material group (in our case steels) dependent correlation between $C$ and $n$. The describen fith step can be seen in Fig. 10, schematically. Sixth step: calculation of the parameters of the limit curves.

The main characteristics of the determined limit curves can be found in Tab. 6 ( $\mathrm{M} \mathrm{t}=$ Mismatch type, Ref = reference). In those cases, when the orientation and/or the path of the propagating crack is known, the values in Tab. 6 can be directly used. In those cases, when $\mathrm{n}$ and $\Delta \mathrm{Kfc}$ values calculated in different directions (T-L and L-T vs. T-S, or $21 \mathrm{~W}$ vs. $23 \mathrm{~W}$ ) are significantly different, and the orientation and/or the growing crack path is not known, the lowest value should be considered from the related ones. The unambiguous determination of the design curves in the near threshold region (near $\Delta K$ th) is difficult. On the one hand, if the threshold stress intensity factor range value ( $\Delta K$ th) is not known, values can be found in the literature (e.g. [21-23]) are usable; furthermore, in special or particular cases, results of virtual testing [24] can be applied, too. On the other hand, the threshold stress intensity factor range value ( $\Delta K$ th), must be reduced by tensile residual stress field and may be increased by compressive residual stress field (e.g. welding residual stresses). $\chi^{2}$ ispravnosti testova (ispitivanje da li uzorak podataka odgovara distribuciji iz određene zastupljenosti, tj. zastupljenosti sa normalnom ili Weibull funkcija distribucije), na nivou značajnosti $\varepsilon=0,05$. Nakon analize zaključeno je da su samo tri parametra Weibull funkcije distribucijeije pogodne za opisivanje svih konfigurisanih uzoraka. Četvrti korak: izračunavanje parametara tri parametrske funkcije Weibull-distribucije. Parametri distribucijskih funkcija su izračunati za sve konfigurisane uzorke koristeći

$$
\mathrm{F}(\mathrm{x})=1-\exp \left[-\left(\frac{\mathrm{x}-\mathrm{N}_{\mathrm{o}}}{\beta}\right)^{1 / \alpha}\right]
$$

jednačinu, gde je N0 parametar praga, $\sigma$ je parametar oblika, a $\beta$ je parametar skale. Peti korak: izbor karakterističnih vrednosti distributivnih funkcija. S obzirom na uticaj parametara materijala na procenu životnog veka, odabrane su karakteristične vrednosti $\Delta K$ th, $\mathrm{n}$ i $\Delta K f c$. Raspon faktora intenziteta graničnog naprezanja ( $\Delta$ Kth) je vrednost koja pripada verovatnoći od $95 \%$, eksponent Paris-Erdogan-ovog zakona (n) je ta vrednost koja pripada verovatnoći od $5 \%$, a žilavost loma zamora $(\Delta \mathrm{Kfc})$ je ta vrednost koja pripada verovatnoći od $5 \%$ za relevantnu funkciju distribucije Weibull-a. Konstanta Paris-Erdogan-a (C) može se izračunati na osnovu grupe materijala (u našem slučaju čelika) zavisne korelacije između C i n. Opisani korak može se šematski videti na slici 10. Šesti korak: izračunavanje parametara granične krive.

Glavne karakteristike utvrđenih graničnih krivih mogu se naći u Tab. 6 ( $\mathrm{M} \mathrm{t}=$ Tip neusklađenosti, Ref $=$ referenca). $U$ onim slučajevima, kada je poznata orijentacija i / ili putanja širenja prslina, vrednosti u Tab. 6 se mogu direktno koristiti. U onim slučajevima, kada su $\mathrm{n}$ i $\Delta K f c$ vrednosti izračunate u različitim smerovima (TL i LT u odnosu na TS, ili $21 \mathrm{~W}$ u odnosu na $23 \mathrm{~W}$ ) značajno se razlikuju, a orijentacija i / ili put rastuće prsline nije poznat, najniža vrednost treba da bude uzeta $u$ obzir. Teško je nedvosmisleno odrediti dizajn krive $\mathrm{u}$ blizini praga (blizu $\Delta \mathrm{K}$ th). $\mathrm{S}$ jedne strane, ako vrednost raspona faktora intenziteta praga naprezanja ( $\Delta$ Kth) nije poznata, vrednosti se mogu naći u literaturi (npr. [21-23]) koje su upotrebljive; Nadalje, u specijalnim ili posebnim slučajevima, mogu se primeniti i rezultati virtualnog testiranja [24]. S druge strane, vrednost raspona faktora intenziteta napona ( $\Delta$ Kth) mora se smanjiti zateznim zaostalim poljem i može povećati pritisnim poljem zaostalih napona (npr. zaostali naponi usled zavarivanja). 


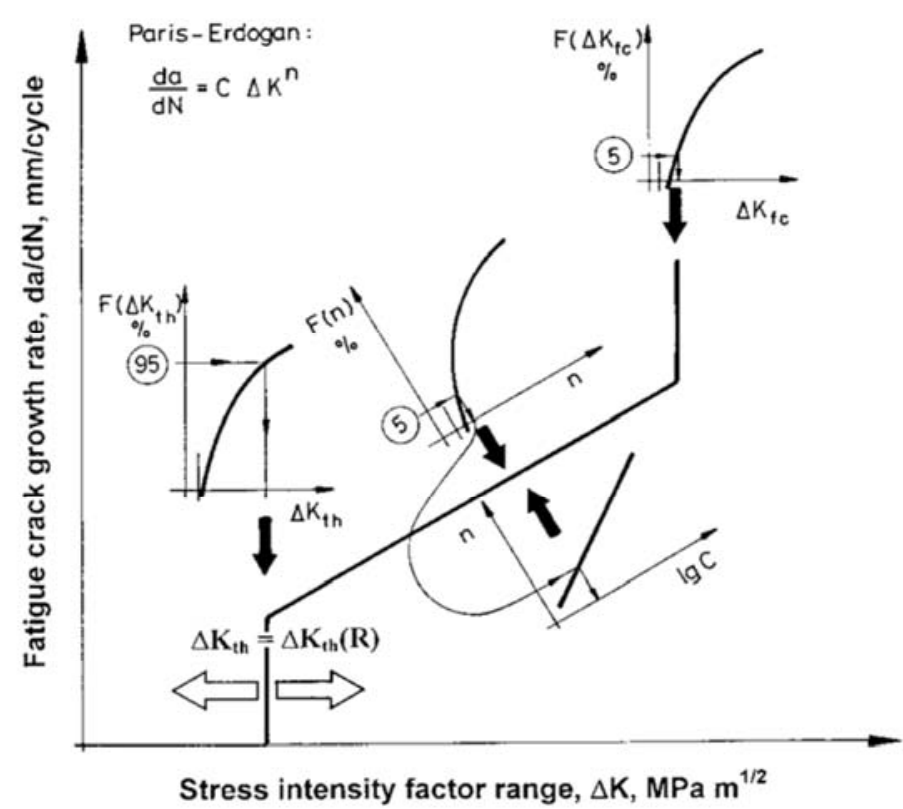

Fig. 10 The proposed method for determination of fatigue crack propagation limit curves SI. 10 Predloženi postupak za određivanje graničnih krivih širenja prslina usled zamora

\begin{tabular}{|c|c|c|c|c|c|c|}
\hline \multirow[t]{2}{*}{ BM } & \multirow[t]{2}{*}{$\mathrm{Mt}$} & \multirow[t]{2}{*}{ Orientation } & $\mathrm{n}$ & C & $\Delta \mathrm{K}_{\mathrm{fc}}$ & \multirow[t]{2}{*}{ Ref } \\
\hline & & & \multicolumn{3}{|c|}{$\left[\mathrm{MPam}^{1 / 2}, \mathrm{~mm} /\right.$ cycle] $^{2}$} & \\
\hline \multirow[t]{2}{*}{ W700E } & \multirow[t]{2}{*}{ BM } & T-L, L-T & 1,70 & $8,09 \mathrm{E}-07$ & 101 & \multirow[t]{2}{*}{ [18] } \\
\hline & & T-S & 1,50 & $2,06 \mathrm{E}-06$ & 75 & \\
\hline \multirow[t]{2}{*}{ W700E } & \multirow[t]{2}{*}{$M$} & $\mathrm{~T}-\mathrm{L} / 21 \mathrm{~W}$ & 4,10 & $1,12 \mathrm{E}-11$ & 105 & \multirow[t]{2}{*}{ [18] } \\
\hline & & T-S/23W & 2,30 & $4,93 \mathrm{E}-08$ & 80 & \\
\hline \multirow[t]{2}{*}{ W700E } & \multirow[t]{2}{*}{ OM } & $\mathrm{T}-\mathrm{L} / 21 \mathrm{~W}$ & 1,85 & $4,02 E-07$ & 96 & \multirow[t]{2}{*}{ [18] } \\
\hline & & $\mathrm{T}-\mathrm{S} / 23 \mathrm{~W}$ & 1,90 & $3,19 \mathrm{E}-07$ & 61 & \\
\hline \multirow[t]{2}{*}{ W700E } & \multirow[t]{2}{*}{$\mathrm{M} / \mathrm{OM}$} & $\mathrm{T}-\mathrm{L} / 21 \mathrm{~W}$ & 2,67 & $8,88 \mathrm{E}-09$ & 90 & \multirow{2}{*}{$\begin{array}{l}\text { this } \\
\text { study }\end{array}$} \\
\hline & & $\mathrm{T}-\mathrm{S} / 23 \mathrm{~W}$ & 2,85 & 3,87E-09 & 67 & \\
\hline W960E & BM & T-S, L-S, T-L & 1,80 & $3,50 \mathrm{E}-07$ & 94 & [19] \\
\hline W960E & $M$ & $\begin{array}{l}\mathrm{T}-\mathrm{L} / 21 \mathrm{~W} \\
\mathrm{~T}-\mathrm{S} / 23 \mathrm{~W}\end{array}$ & 2,75 & $1,03 E-08$ & 93 & [20] \\
\hline \multirow[t]{2}{*}{ A960M } & \multirow[t]{2}{*}{ BM } & $T-L, L-T$ & 1,82 & $4,63 \mathrm{E}-07$ & 116 & \multirow[t]{2}{*}{ [18] } \\
\hline & & $\mathrm{T}-\mathrm{S}$ & 1,75 & $6,41 \mathrm{E}-07$ & 87 & \\
\hline \multirow[t]{2}{*}{ A960M } & \multirow[t]{2}{*}{ UM } & $\mathrm{T}-\mathrm{L} / 21 \mathrm{~W}$ & 2,40 & $3,10 \mathrm{E}-08$ & 115 & \multirow[t]{2}{*}{ [18] } \\
\hline & & T-S/23W & 2,15 & $9,93 \mathrm{E}-08$ & 67 & \\
\hline \multirow[t]{2}{*}{ A960M } & \multirow[t]{2}{*}{$M$} & $\mathrm{~T}-\mathrm{L} / 21 \mathrm{~W}$ & 1,90 & $3,19 \mathrm{E}-07$ & 114 & \multirow[t]{2}{*}{ [18] } \\
\hline & & $\mathrm{T}-\mathrm{S} / 23 \mathrm{~W}$ & 2,75 & $6,06 \mathrm{E}-09$ & 82 & \\
\hline
\end{tabular}

Tab. 6 Characteristics of the determined fatigue crack propagation limit curves

Tab. 6. Karakteristike utvrđenih graničnih krivih širenja prslina usled zamora

\section{Summary and conclusions}

Based on our investigations and their results the following conclusions can be drawn.

The results of the executed investigations justified the necessity of statistical approaches, especially referring to the directions of the base materials and the welded joints, and the determination of the number of the tested specimens.

The applied gas metal arc welding process and the used technological parameters are suitable for production welded joints with appropriate quality,

\section{Rezime i zaključci}

$\mathrm{Na}$ osnovu naših istraživanja i njihovih rezultata mogu se doneti sledeći zaključci.

Rezultati izvršenih istraživanja opravdali su neophodnost statističkih pristupa, posebno se odnose na smer osnovnog materijala i zavarene spojeve, kao i određivanje broja ispitivanih uzoraka. Primenjeni postupak elektrolućnog zavarivanja u zaštiti gasa i korišćeni tehnološki parametri pogodni su za izradu zavarenih spojeva odgovarajućeg kvaliteta, pri čemu odgovarajući kvalitet sadrži 
where the appropriate quality contains the eligible resistance to fatigue crack propagation.

The welding causes unfavourable effects both on the mechanical properties and the fatigue crack growth resistance of the high strength steels.

The average values of the Paris-Erdogan exponents (n) of Weldox 700E and Alform 960M base materials in the T-L and L-T directions and of the Weldox $960 \mathrm{Q}$ base material in the T-S and L-S directions are significantly not different, which means equal fatigue crack growth resistance in these orientations. The average values of the ParisErdogan exponent (n) of Weldox 700E and Alform $960 \mathrm{M}$ base materials in the T-S orientation and of the Weldox 960Q base material in the $T-L$ orientation are significantly different. The fatigue crack growth resistance of the Weldox $700 \mathrm{E}$ material is more unfavourable in T-S direction. The material strength category (in our case $690 \mathrm{MPa}$ or $960 \mathrm{MPa}$ ) and the production condition (in our case quenching and tempering or thermomechanically treating) cause significant effect on the fatigue crack growth resistance, too.

The average values of the Paris-Erdogan exponents $(n)$ of the matching $(M)$, overmatching $(\mathrm{OM})$, matching / overmatching (M/OM) and undermatching (UM) conditions of the investigated welded joints were statistically higher than the exponents of the concerning base materials.

The average value of the Paris-Erdogan exponent $(\mathrm{n})$ of the overmatching (OM) welded joint of the Weldox 700E is lower than the exponent of both the matching (M) and the matching/overmatching (M/OM) conditions. The fatigue crack growth resistance under overmatching (OM) condition is lower than both matching (M) and matching/overmatching (M/OM) conditions. It means that the matching/overmatching (M/OM) mismatch type is more beneficial than the overmatching (OM) type.

The average value of the Paris-Erdogan exponent $(\mathrm{n})$ of the matching $(\mathrm{M})$ welded joint of the Alform $960 \mathrm{M}$ is lower than the exponent of the undermatching (UM) condition. The fatigue crack growth resistance under matching $(\mathrm{M})$ condition is lower than undermatching (UM) condition.

The determined results fundamentally refer to reliable and reproducible examinations. Unfortunately, the standard deviation coefficients are in some cases too high (Paris- Erdogan exponent (n), T-S, $21 \mathrm{~W}$ and $23 \mathrm{~W}$ orientations).

Based on these results and the used methods fatigue crack propagation limit curves can be determined for the investigated high strength base materials and their gas metal arc welded joints, prihvatljivi otpor protiv širenja prslina.

Zavarivanje izaziva nepovoljne efekte i na mehanička svojstva i na otpornost na rast prslina kod čelika visoke čvrstoće.

Prosečne vrednosti Paris-Erdogan-ovih eksponenata (n) Weldox 700E i Alform 960M osnovnih materijala u pravcima TL i LT i materijala Weldox $960 \mathrm{~K}$ u pravcu TS i LS značajno se ne razlikuju, što znači jednak otpor rastu prslina usled zamora u ovim orijentacijama. Prosečne vrednosti Paris-Erdogan-ovih eksponenata (n) Weldox 700E i Alform 960M osnovnih materijala u T-S orijentaciji i Weldox 960K osnovnog materijala u T-L orijentaciji su značajno različite. Otpor na rast prslina usled zamora materijala Weldox $700 E$ je nepovoljniji u T$S$ smeru. Kategorija čvrstoće materijala (u našem slučaju $690 \mathrm{MPa}$ ili $960 \mathrm{MPa}$ ) i stanje proizvodnje (u našem slučaju kaljenje i otpuštanje ili termomehanička obrada) takođe imaju značajan uticaj na otpornost na rast prslina.

Prosečne vrednosti Paris-Erdogan-ovih eksponenata (n) kod uslova podudaranja (M), jačeg (OM), podudaranja / jačeg (M / OM) i slabijeg (UM) ispitivanih zavarenih spojeva su statistički veće od eksponenata za osnovne materijale.

Prosečna vrednost Paris-Erdogan eksponenta (n) jačeg (OM) zavarenog spoja Weldox 700E je niža od eksponenta i uslova podudaranja (M) i podudaranja / jačeg (M / OM) uslova. Otpor rasta prslina usled zamora pod uslovima jačeg (OM) je niži od uslova podudaranja (M) i uslova podudaranja / jaćeg (M / OM). To znači da je tip neusklađenosti, podudaranje / jači (M / OM), povoljniji od tipa jačeg (OM).

Prosečna vrednost Paris-Erdogan eksponente (n) podudarajućeg (M) zavarenog spoja Alform 960M je niža od eksponenta za uslov slabijeg (UM). Otpor na rast prslina usled zamora pod podudarajužim (M) uslovima je niži od uslova slabijeg (UM).

Utvrđeni rezultati se u osnovi odnose na pouzdana i ponovljiva ispitivanja. Nažalost, standardni koeficijenti devijacije su u nekim slučajevima previsoki (Paris-Erdogan eksponent (n), T-S, $21 \mathrm{~W}$ i 23W orijentacije).

$\mathrm{Na}$ osnovu ovih rezultata i korišćenim metodama mogu se utvrditi granične krive širenja prslina za ispitivane osnovne materijale i njihove zavarene spojeve postupkom elektročućnog zavarivanja u zaštiti gasa, upotrebom pojednostavljene metode [6]. Granične krive s jedne strane tačno odražavaju karakteristike rasta prslina usled zamora i osnovnih materijala i zavarenih spojeva, s druge strane se mogu koristiti za kritičku procenu inženjerskih analiza (ECA) i proračune strukturnog integriteta: 
using simplified method [6]. The limit curves on the one hand correctly reflect the fatigue crack growth characteristics of both the base materials and the welded joints, on the other hand are usable for engineering critical assessment (ECA) and structural integrity calculations:

- determination of propagable an critical crack sizes;

- calculation of lifetime determined by the propagable crack size;

- calculations of remaining lifetime functions, influences on the lifetime values and lifetime function (in other words parameter study);

- reliability of remaining lifetime estimation;

- calculation of damage parameter and damage function [25].

Further examinations required in order to draw statistically better established conclusions, to measure threshold stress intensity factor range ( $\Delta \mathrm{K}$ th) values for base materials and welded joints, and finally, to study the effects of the welding residual stress fields.

\section{Acknowledgements}

The presented work was carried out as part of the EFOP- 3.6.1-16-2016-00011 "Younger and Renewing University - Innovative Knowledge City institutional development of the University of Miskolc aiming at intelligent specialization" project implemented in the framework of the Széchenyi 2020 program. The realization of this project is supported by the European Union, co-financed by the European Social Fund.

\section{References}

[1] Allen RJ, Booth GS and Jutla T 1988 Fatigue and Fracture of Engineering Materials and Structures 11/1 45

[2] Allen RJ, Booth GS and Jutla T 1988 Fatigue and Fracture of Engineering Materials and Structures 11/2 71

[3] Ohta A, Maeda Y, Kosuge M, Machida S and Yoshinari $H$ 1989 Transactions of the Japan Welding Society 20/1 17

[4] Merkblatt DVS 2401 Teil 1 Oktober 1982 Bruchmechanische Bewertung von Fehlern in Schweissverbindungen. Grundlagen und Vorgehensweise

[5] Det norske Veritas, Classification Notes, Note No. 30.2 August 1984 Fatigue strength analysis for mobile offshore units [6] BS 79101999 Guide on methods for assessing the acceptability of flaws in fusion welded structures

[7] Merkblatt DVS 2401 Teil 2 April 1989 Bruchmechanische Bewertung von Fehlern in Schweissverbindungen. Praktische Anwendung

[8] Paris P and Erdogan F 1963 Journal of Basic Engineering, Transactions of the ASME 528

[9] Lukács J 1992 Reliability of Cyclic Loaded Welded Joints Having Cracks CSc dissertation (in Hungarian)

[10] Lukács J 2003 Materials Science Forum 414-415 31

[11] Gáspár M, Balogh A and Sas I 2015 Proceedings of IIW 2015 International Conference, Paper IIW 201515041

[12] Kalácska E, Májlinger K, Fábián ER and Spena PR 2017 Materials Science Forum 88580

[13] Májlinger K, Kalácska E and Spena PR 2016 Materials Design 109615
- određivanje kritične veličine prsline koje se može proširiti;

- izračunavanje životnog veka utvrđenog veličinom prsline koja se širi;

- proračun preostalih radnih funkcija, uticaj na vrednosti radnog veka i funkciju radnog veka (drugim rečima, studija parametara);

- pouzdanost procene preostalog radnog veka;

- proračun parametra oštećenja i funkcije oštećenja [25].

Potrebna su dalja ispitivanja kako bi se izvukli statistički bolje utvrđeni zaključci, izmerili vrednosti praga faktora intenziteta napona ( $\Delta \mathrm{K}$ th) za osnovne materijale i zavarene spojeve i, na kraju, da bi se proučio efekat zaostalih polja zaostalih napona usled zavarivanja.

\section{Priznanja}

Predstavljeni rad sproveden je u okviru projekta EFOP-3.6.1-16-2016-00011 „Mlađi i obnavljajući univerzitet - Inovativni grad znanja - institucionalni razvoj Univerziteta u Miskolcu sa ciljem inteligentne specijalizacije" koji se realizuje u okviru Szechenii 2020 program. Realizaciju ovog projekta podržava Evropska unija, a sufinansira ga Evropski socijalni fond.

[14] Gáspár M, Balogh A 2013 Production Processes and Systems 6(1) 9

[15] Dobosy Á, Gáspár M and Jámbor P 2017 3rd Young Welding Professionals International Conference (YPIC2017), Halle (Saale) 1

[16] https://hks-prozesstechnik.de/en/about-hks/ accessed 11 January 2019

[17] ASTM E647-11e1 2011 Standard Test Method for Measurement of Fatigue Crack Growth Rate

[18] Dobosy Á 2017 Design limit curves for high strength steel structures under cyclic loading condition PhD thesis (in Hungarian)

[19] Lukács J 2012 Bányászati és Kohászati Lapok Bányászat 14543 (in Hungarian)

[20] Lukács J and Dobosy Á 2017 IIW-DOC XIII-2692-17

[21] Ritchie RO 1979 International Materials Reviews 5-6 205

[22] Taylor D 1985 Compendium of Fatigue Thresholds and Crack Growth Rates EMAS, Warley

[23] Taylor D and Jianchun L (Eds.) 1993 Sourcebook on fatigue crack propagation: threshold and crack closure EMAS, Warley

[24] Farahmand B 2008 Multiscale Fatigue Crack Initiation and Propagation of Engineering Materials: Structural Integrity and Microstructural Worthiness, Solid Mechanics and its Applications 152 Springer, Dordrecht 1

[25] Lukács J 2003 Metal Structures - Design, Fabrication, Economy Millpress, Rotterdam 